\title{
Levels of Heavy Metals in Fishes (Cheilinus trilobatus) from the Gulf of Aqaba, Jordan
}

\author{
Tariq Al-Najjar ${ }^{1 *}$, Rana Al-Momani' ${ }^{1}$ Maroof Khalaf ${ }^{1}$, Mohammad Wahsha², \\ Majduleen Sbaihat ${ }^{1}$, Nooman Khalaf ${ }^{3}$, Khalid Abu Khadra4, Haneen Magames ${ }^{1}$ \\ ${ }^{1}$ Department of Marine Biology, The University of Jordan, Aqaba Branch, Jordan \\ ${ }^{2}$ Marine Science Station, The University of Jordan, Aqaba Branch, Jordan \\ ${ }^{3}$ Al-Ahliyya Amman University, Faculty of Pharmacy and Medical Sciences, Jordan \\ ${ }^{4}$ Department of Biological Sciences, Yarmouk University, Irbid, Jordan \\ Email: ${ }^{t}$.najjar@ju.edu.jo
}

Received 18 April 2016; accepted 21 June 2016; published 24 June 2016

Copyright (C) 2016 by authors and Scientific Research Publishing Inc.

This work is licensed under the Creative Commons Attribution International License (CC BY).

http://creativecommons.org/licenses/by/4.0/

(c) $)$ (i) 0 pen Access

\begin{abstract}
Heavy metal concentrations of $\mathrm{Ni}, \mathrm{Mg}, \mathrm{Co}, \mathrm{Cr}, \mathrm{Cd}$ and $\mathrm{Cu}$ were investigatedusing flame Atomic $\mathrm{Ab}$ sorption Spectrophotometer (AAS) in the liver, kidney, muscle, scale, gonad, gill and stomach of Cheilinus trilobatus fish species from the northern Gulf of Aqaba. Cheilinus trilobatus fish species were collected during the period May to August 2013. The results indicated significant differences between different organs of Cheilinus trilobatus for $\mathrm{Ni}(p=0.0002)$, Fe $(p=0.0213), \mathrm{Co}(p<0.0001)$ and $\mathrm{Mg}(p<\mathbf{0 . 0 0 0 1})$. However, $\mathrm{Cu}$ and $\mathrm{Cd}$ did not show any significant differences. The results revealed week correlation between different metal concentrations in Cheilinus trilobatus and its length. The levels of metal concentration of the present study were generally lower or within the ranges of those found in the fish of the Red Sea. After all, Cheilinus trilobatus fish species was found to be safe for consumption and do not pose a significant threat to the health of human consumers.
\end{abstract}

\section{Keywords}

Heavy Metals, Fishes, Levels, Concentrations, Aqaba, Red Sea

\section{Introduction}

The term heavy metals are a general collective term which applies to group of metals and metalloids with atomic

\footnotetext{
"Corresponding author.
}

How to cite this paper: Al-Najjar, T., Al-Momani, R., Khalaf, M., Wahsha, M., Sbaihat, M., Khalaf, N., Khadra, K.A. and Magames, H. (2016) Levels of Heavy Metals in Fishes (Cheilinus trilobatus) from the Gulf of Aqaba, Jordan. Natural Science, 8 , 256-263. http://dx.doi.org/10.4236/ns.2016.86030 
density greater than $4 \mathrm{~g} / \mathrm{cm}^{3}$ or 5 times or more great than water [1], they are also known as trace elements because they occur in minute concentrations in biological systems. Some of these metals are toxic to living organisms even at low concentrations, whereas others are biologically essential and become toxic at relatively high concentrations. When ingested in excess amounts heavy metals combine with body's bio-molecules, like proteins and enzymes to form stable bio-toxic compounds, thereby mutilating their structures and hindering them from the bio-reactions of their functions [1].

Metals entering the aquatic ecosystem can be deposited in aquatic organisms through the effects of bio-concentration, bioaccumulation via the food chain process and become toxic when accumulation reaches a substantially high level [2]. In fish, which is often at the higher level of the aquatic food chain, substantial amounts of metals may accumulate in their soft and hard tissues [3].

Several studies reveal a susceptibility of the Gulf of Aqaba to metal pollution [4]-[9] these studies stated that the Gulf of Aqaba is surrounded mostly by dry desert lands, thus, it has a great chance to get polluted with metals carried by air winds. After the year 2000, Aqaba was declared as a special economic zone. The chance for pollution to occur has increased in the Jordanian sector of the Gulf of Aqaba, especially the chance for metal pollution due to the developments that were made along the coastline of the Gulf, represented by the projects carried out in different fields such as industry and tourism [9]. Cheilinus trilobatus is of limited market value, it is found in shallow reefs especially in areas of rich coral and algal growth; solitary and does not congregate in large numbers as adults. It feeds mostly on molluscs, crustaceans and sea urchins. It is seen at depths down to 15 $\mathrm{m}$. This species is endemic to the Red Sea [10].

This study aims to investigate the presence of some heavy metals contaminants ( $\mathrm{Cd}, \mathrm{Cu}, \mathrm{Ni}, \mathrm{Co}, \mathrm{Mg}$ and $\mathrm{Fe}$ ) in muscles, gills, livers, kidney, gonads, stomach and scales of Cheilinus trilobatus fish collected from the Gulf of Aqaba, Red Sea.

\section{Materials and Methods}

\subsection{Study Area}

The Gulf of Aqaba is located at the east fork of the Red Sea (Figure 1). Its coasts are shared by Jordan, Palestine, Egypt and Saudi Arabia. The climate is arid with high evaporation ( $\sim 400 \mathrm{~cm} /$ year) and negligible precipitation ( $\sim 2.2 \mathrm{~cm} /$ year) and runoff. The mean sea surface temperatures are $23.5^{\circ} \mathrm{C}$ and mean salinity values in the upper waters are 40.4 - 40.6. Extremely oligotrophic conditions are prevailing in the Gulf due to the arid climate and because it receives its waters from the nutrient-depleted Red Sea surface waters through the Straits of Tiran.

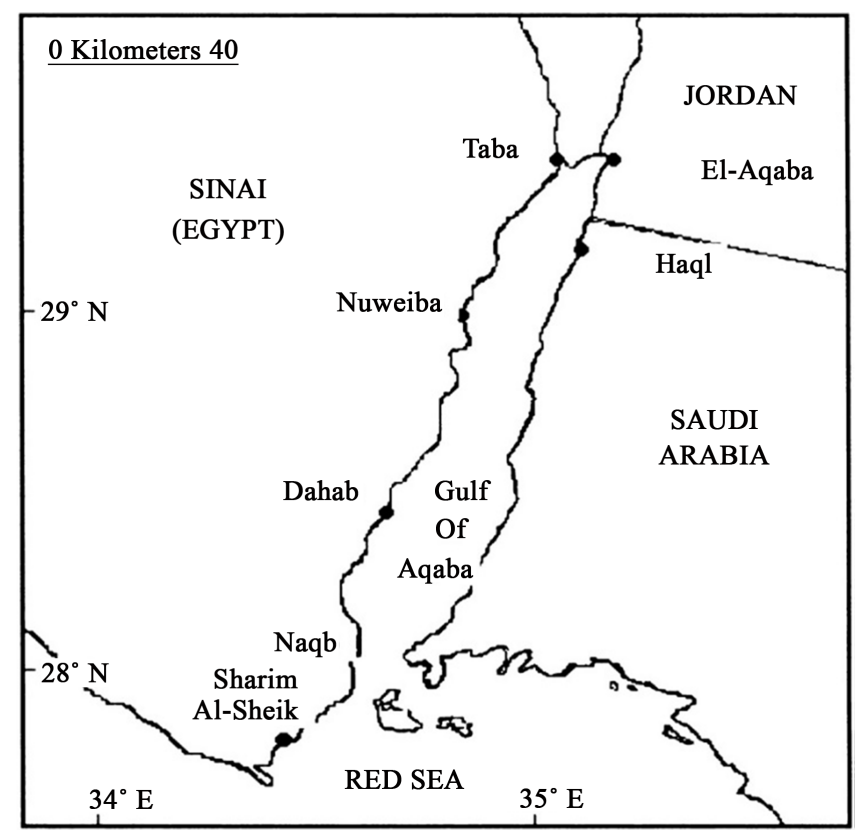

Figure 1. Study area. 
The deep light penetration and high transparency due to low amount of resuspended materials and fresh water flux results in extending the depth limit of massive hermatypic corals such as Porites down to 40 - $50 \mathrm{~m}$ [11]. The Gulf biodiversity is unique, and some species are endemic to the area. It gained a high and unique biodiversity due to its semi enclosed nature, which also makes it more susceptible to pollution with these metals.

\subsection{Sample Collection and Treatments}

The Fish samples were collected by traps from the coastal areas of the Gulf of Aqaba by local fishermen during the period May to August 2013. After that, the collected specimens were kept in cleaned plastic bags and transferred to the laboratory. In the laboratory the collected samples were classified according to [10]. The identified Cheilinus trilobatus samples were rinsed by distilled water to get rid of any remnants of trace metals on the outer surface of the fish. Then fishes were dissected using a stainless steel knife, size and weight were measured. Samples of different organs (liver, kidney, muscle, scale, gonad, gill and stomach) from each fish were taken, dried at $85^{\circ} \mathrm{C}$ to constant weight and then were ground into powder. Sub-sample from each organ $(0.1-0.5 \mathrm{mg} /$ dry. wt.) were burned using muffle furnace at $550^{\circ} \mathrm{C}$, samples were cooled to room temperature and then digested in acid cleaned jars with hot concentrated nitric acid to obtain release of heavy metals. All organic materials in each sample were completely digested. The digests were allowed to cool, filtered through a $0.45 \mu \mathrm{m}$ Millipore membrane filter, transferred to $25 \mathrm{ml}$ volumetric flasks and made up to mark with $1 \%$ nitric acid and diluted with double distilled water to $25 \mathrm{ml}$. The digests were kept in plastic bottles, heavy metals, $(\mathrm{Cd}, \mathrm{Cu}, \mathrm{Ni}$, Co, $\mathrm{Mg}$ and $\mathrm{Fe}$ ) concentrations were determined using Atomic Absorption Spectrophotometer (AAS) [12] available at the Marine Science Station. Metal contents were expressed as $\mu \mathrm{g} \cdot \mathrm{g}^{-1}$ dry weight.

\subsection{Statistical Analysis}

Statistical analysis was based on ANOVA and is presented as means \pm S.D. The statistical significance was declared when p value was equal to or less than 0.05 . Statistical analyses were performed using Sigma Stat statistical software version 3.5.

\section{Results}

\subsection{Metal Concentrations between Organs}

Mean metal concentrations for $\mathrm{Cu}, \mathrm{Ni}, \mathrm{Cd}, \mathrm{Fe}, \mathrm{Co}$ and $\mathrm{Mg}$ in Cheilinus trilobatus for different fish organs (muscles, kidney, gill, gonad, liver, scale and stomach) were analyzed and shown in Figure 1. The results indicated significant differences between different organs of Cheilinus trilobatus for $\mathrm{Ni}(p=0.0002)$, Fe ( $p=0.0213)$, Co $(p<0.0001)$ and $\mathrm{Mg}(p<0.0001)$ However, $\mathrm{Cu}$ and $\mathrm{Cd}$ didn't show any significant differences. The present study revealed that the highest $\mathrm{Cu}$ concentration was found in the kidney $(81.58 \mu \mathrm{g} / \mathrm{g})$, followed by gonad $(28.80$ $\mu \mathrm{g} / \mathrm{g})$, muscle $(11.32 \mu \mathrm{g} / \mathrm{g})$, scale $(10.06 \mu \mathrm{g} / \mathrm{g})$, liver $(7.68 \mu \mathrm{g} / \mathrm{g})$ and gill $(6.87 \mu \mathrm{g} / \mathrm{g})$ and the lowest Cu concentration was recorded in stomach $(6.61 \mu \mathrm{g} / \mathrm{g})$. The highest Ni concentration was found in the kidney $(122.42$ $\mu \mathrm{g} / \mathrm{g})$, followed by gonad $(63.50 \mu \mathrm{g} / \mathrm{g})$, liver $(14.41 \mu \mathrm{g} / \mathrm{g})$, scale $(13.73 \mu \mathrm{g} / \mathrm{g})$ gill $(10.29 \mu \mathrm{g} / \mathrm{g})$, and muscle (6.99 $\mu \mathrm{g} / \mathrm{g})$ and the lowest $\mathrm{Ni}$ concentration was recorded in stomach $(3.76 \mu \mathrm{g} / \mathrm{g})$. For Cd, the highest concentration was found in the kidney $(7.64 \mu \mathrm{g} / \mathrm{g})$, followed by stomach $(1.81 \mu \mathrm{g} / \mathrm{g})$, scale $(1.64 \mu \mathrm{g} / \mathrm{g})$, gonad $(1.41 \mu \mathrm{g} / \mathrm{g})$, gill $(1.08 \mu \mathrm{g} / \mathrm{g})$ and liver $(0.81 \mu \mathrm{g} / \mathrm{g})$ and the lowest $\mathrm{Cd}$ concentration was recorded in muscle $(0.41 \mu \mathrm{g} / \mathrm{g})$. The highest Fe level was recorded in kidney $(3054.99 \mu \mathrm{g} / \mathrm{g})$, followed by gonad $(1615.98 \mu \mathrm{g} / \mathrm{g})$, liver $(456.34 \mu \mathrm{g} / \mathrm{g})$, stomach $(268.82 \mu \mathrm{g} / \mathrm{g})$, scale $(210.37 \mu \mathrm{g} / \mathrm{g})$ and gill $(181.99 \mu \mathrm{g} / \mathrm{g})$, respectively; and the lowest one was found in muscle $(151.94 \mu \mathrm{g} / \mathrm{g})$. The highest concentration for Co was found in kidney $(167.81 \mu \mathrm{g} / \mathrm{g})$ and the lowest concentration was found in stomach $(7.15 \mu \mathrm{g} / \mathrm{g})$. The highest $\mathrm{Mg}$ concentration was also found in kidney $(3765.09$ $\mu \mathrm{g} / \mathrm{g})$ and the lowest concentration in stomach $(222.06 \mu \mathrm{g} / \mathrm{g})$ as shown in Figure 2.

\subsection{Correlation between Body Length and Trace Metal Concentration}

The linear regression between different element concentrations and Cheilinus trilobatus length are shown in Figure 3. The data showed week correlation between different element concentrations in Cheilinus trilobatus and length. The correlation between different heavy metals showed that, the highest correlation was found between $\mathrm{Ni}$ and Co $\left(\mathrm{R}^{2}=0.71\right)$, Co and Fe $\left(\mathrm{R}^{2}=0.28\right)$, Ni and $\mathrm{Mg}\left(\mathrm{R}^{2}=0.70\right)$ and between Co and $\mathrm{Mg}\left(\mathrm{R}^{2}=0.72\right)$ (Figure 4). 

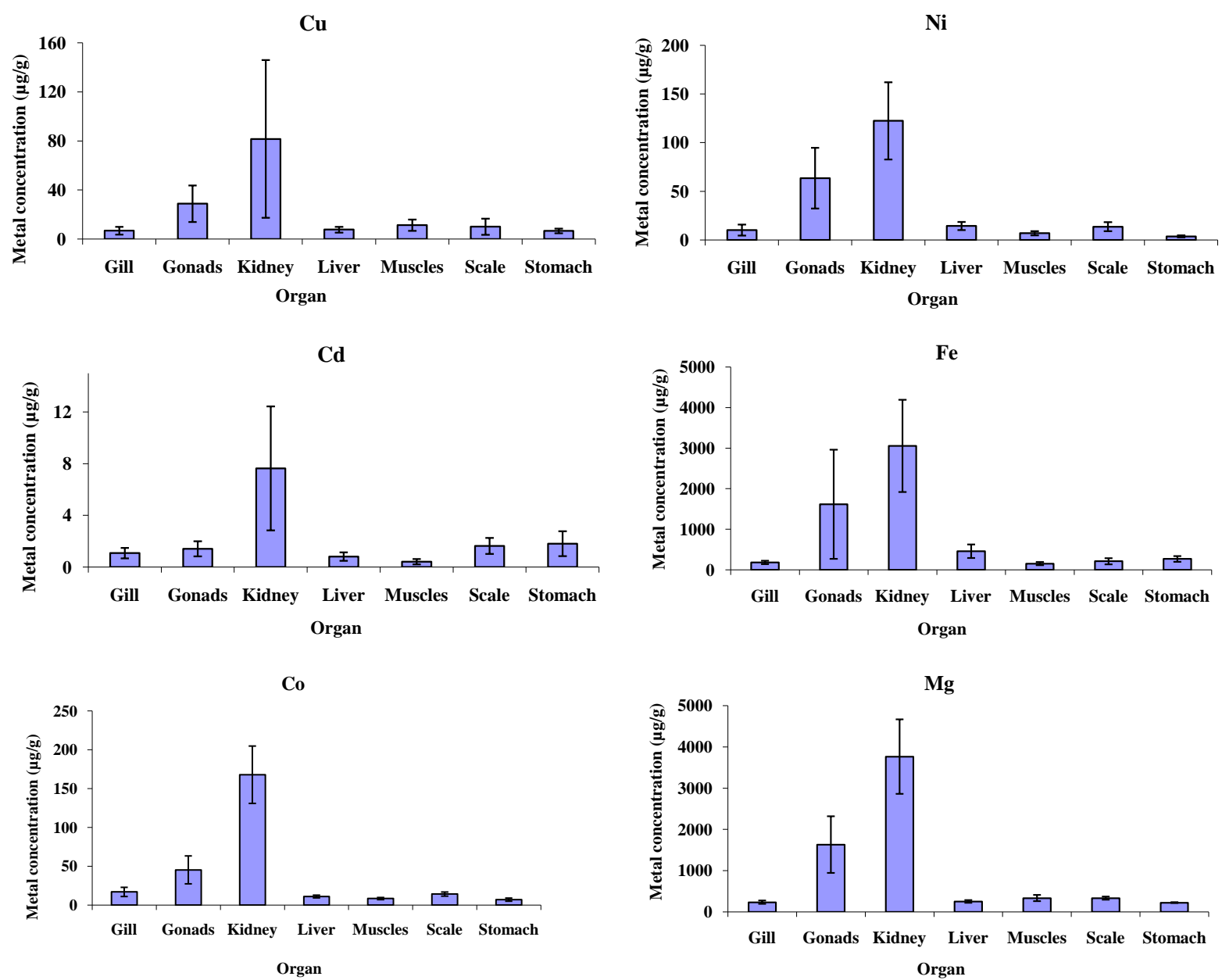

Figure 2. Mean concentrations $\pm \mathrm{SD}$ of $\mathrm{Cu}, \mathrm{Ni}, \mathrm{Cd}, \mathrm{Fe}, \mathrm{Co}$ and $\mathrm{Mg}$ in the various organs: gills, gonads, kidneys, livers, muscles, scales and stomach of Cheilinus trilobatus.
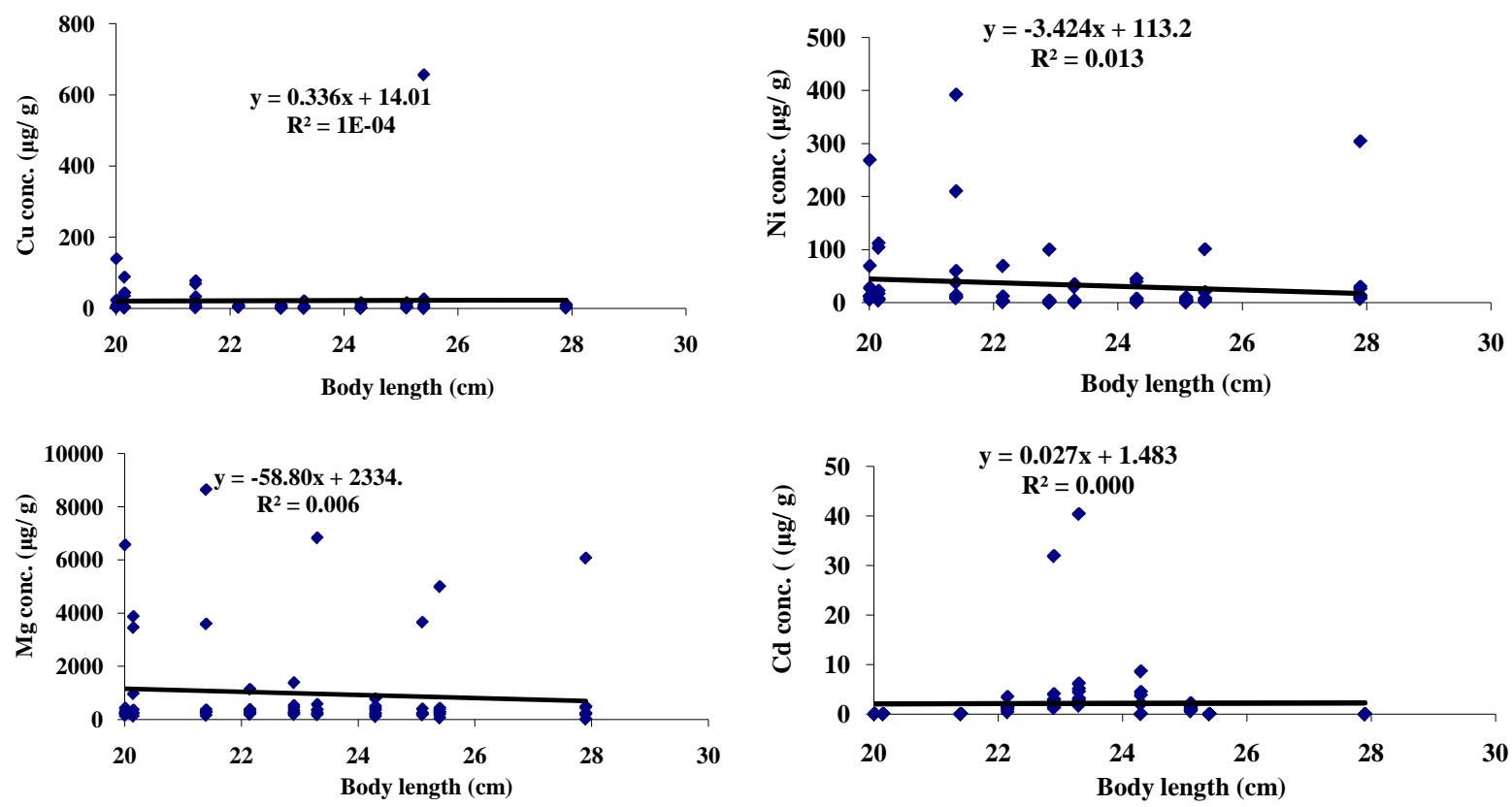

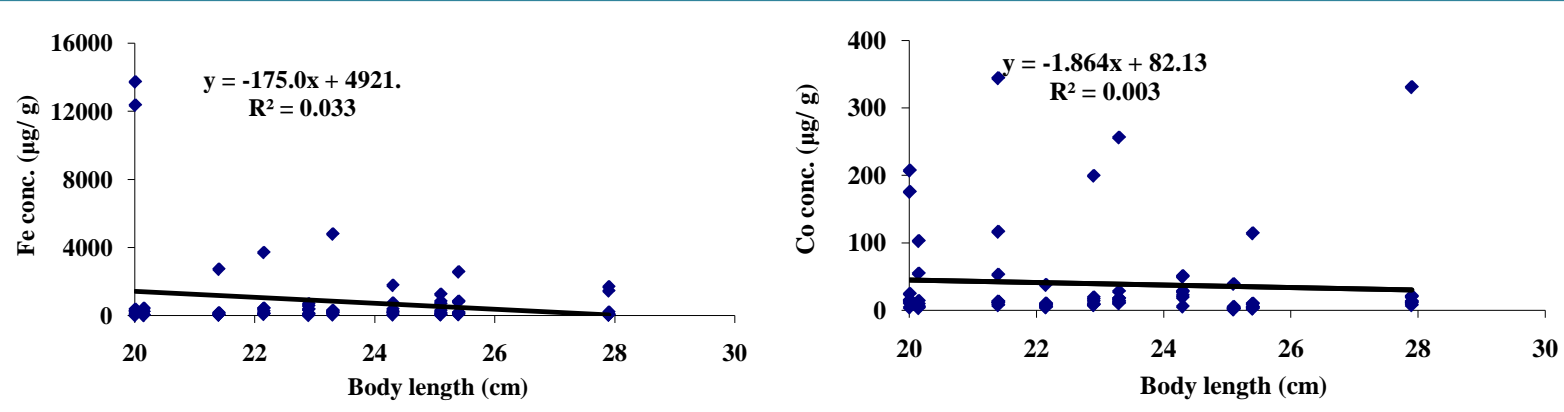

Figure 3. Correlation between Cheilinus trilobatus body length and metal concentration.
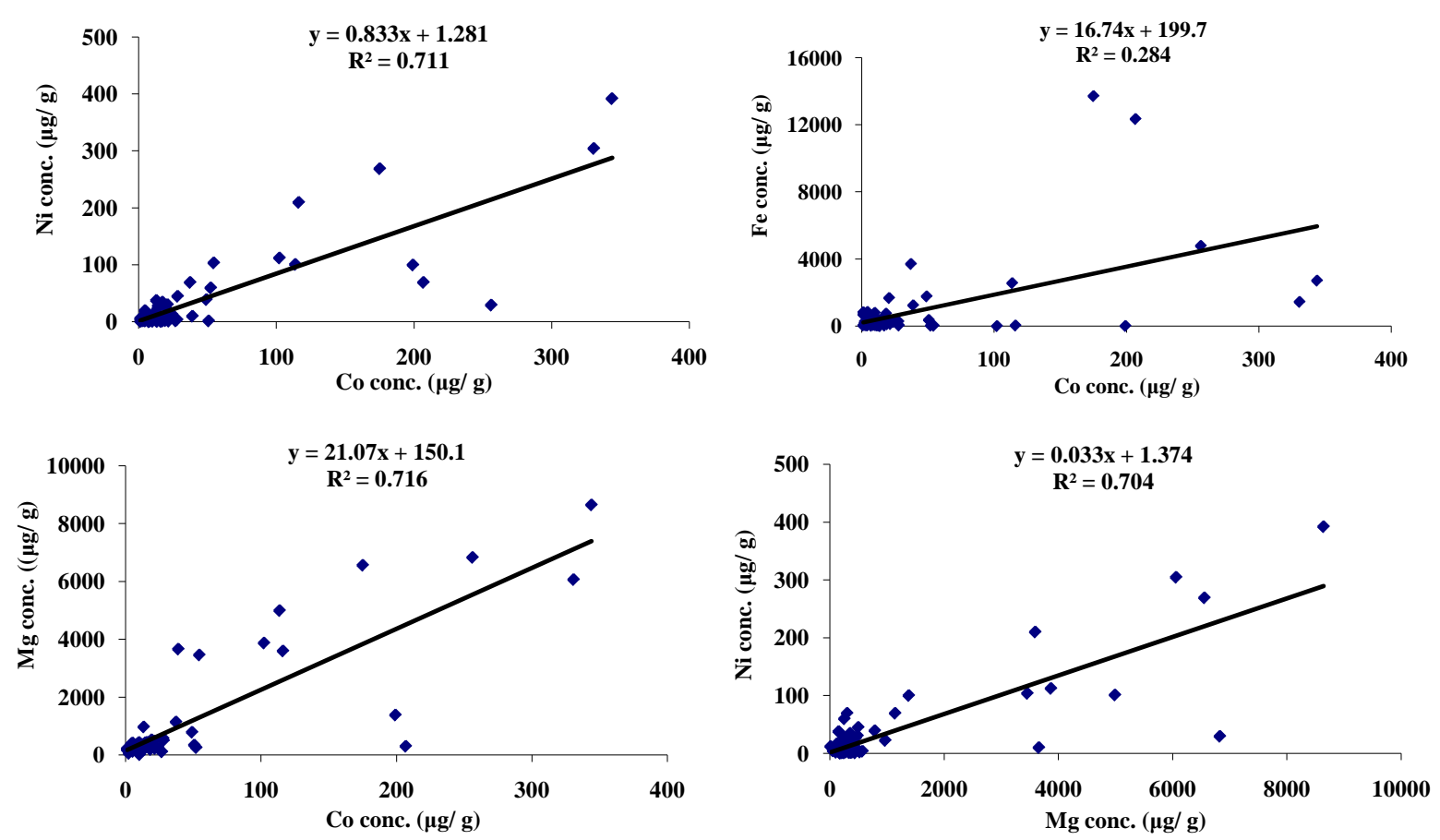

Figure 4. Correlation between metal concentrations of Cheilinus trilobatus.

\section{Discussion}

Due to the toxicity of heavy metals and their accumulation in biota, the assessment and determination of the concentration levels of heavy metals in commercial fish species have reached a considerable level of attention in different countries and organizations around the world. This interest aimed to insure the safety of the food supply, to minimize the potential hazard effect on human health and to evaluate ecosystem situation.

The stomach, gills, kidney, liver, muscle, scale and gonad of the Cheilinus trilobatus collected from the deep waters of the Gulf of Aqaba were analyzed for 6 trace metals. The mean concentrations of heavy metals among the organs were significant difference for $\mathrm{Ni}(p=0.0002), \mathrm{Mg}(p<0.0001), \mathrm{Fe}(p=0.0213)$ and $\mathrm{Co}(p<0.0001)$ but not significant difference for $\mathrm{Cu}$ and $\mathrm{Cd}$. The highest concentrations were for both kidneys and livers and the lowest concentrations were for muscles in agreement with the previous studies for other fishes of the Gulf of Aqaba and other regions in which kidneys and livers are the site of sink of heavy metals and detoxification (Table 1).

Copper is an essential element, it is very toxic and, the Maximum permissible limit of $\mathrm{Cu}$ is $100 \mu \mathrm{g} / \mathrm{g}$ [13]. However, a high intake of $\mathrm{Cu}$ has been recognized to cause adverse health problems [14]. Copper level in the present study indicates much lower mean value in muscle. Nickel can cause respiratory problems and it is carcinogenic, its acute toxicity arises from competitive interaction with five major essential elements namely: calcium, cobalt, copper, iron and zinc [15]. Nickel level in the present study indicates low mean value in muscle; 
however, there is no information about the maximum permissible nickel limits in fish tissues. The highest mean value of $\mathrm{Cd}$ in the present study was in kidney $7.64 \mu \mathrm{g} / \mathrm{g}$. This is in agreement with the Environmental Health Criteria of Cd [16] and [17] which reported that Cd is accumulated in the body in various tissues, but the main sites of accumulation in aquatic organisms are the kidney and liver; the maximum permissible limit for Cd is $3.33 \mu \mathrm{g} / \mathrm{g}$ [13]. Cadmium level in the present study indicates lower mean value in muscle. The Maximum permissible limit of Fe in fish muscle is $333.33 \mu \mathrm{g} / \mathrm{g}$ [13], Our results indicate much lower values for Fe. Cobalt is beneficial for humans because it is part of vitamin B12. Exposure to high levels of cobalt can result in lung and heart effects and dermatitis, cobalt concentrations in the literature have been reported in the range of $0.02-0.67$ $\mathrm{mg} / \mathrm{kg}$ for muscles of fish from the fish markets in India [18], $0.006-0.244 \mu \mathrm{g} / \mathrm{g}$ for muscles of fish from the coastal waters of the Caspian Sea [19], $0.04-0.41 \mu \mathrm{g} / \mathrm{g}$ for muscles and $0.14-0.51 \mu \mathrm{g} / \mathrm{g}$ for livers of fish from Turkish seas [20]. Our results were generally similar to those studies. There is no information about maximum permissible limits for cobalt and magnesium in fish tissues.

The metals concentrations the Cheilinus trilobatus muscle tissues were found to be same or less of these metals found in the previous examined fish species from the Gulf of Aqaba and fall below the accepted levels for human consumption recommended by FAO and by WHO which means that they do not pose a significant threat to the health of human consumers (Table 2). There was no significant correlation of trace metal of $(\mathrm{Cu}, \mathrm{Ni}, \mathrm{Cd}$, $\mathrm{Fe}, \mathrm{Co}$ and $\mathrm{Mg}$ ) contents with Cheilinus trilobatus size this may attributed to the limited range size $(20-28 \mathrm{~cm})$ of the collected fish.

\section{Conclusion}

Metal concentrations in the three studied fish species were within the same range or lower than other species from previous studies in the Jordanian water or elsewhere. The results showed that metal accumulation varied between organs, the highest concentrations were for Kidney and livers, the lowest concentrations for muscles,

Table 1. Maximum permissible limit of heavy metals in fish muscle ( $\mu \mathrm{g} / \mathrm{g}$ dry. wt.) according to the international standards.

\begin{tabular}{|c|c|c|c|c|}
\hline \multirow{2}{*}{ International standards } & \multicolumn{3}{|c|}{ Heavy metals in fish muscles ( $\mu \mathrm{g} / \mathrm{g}$ dry. wt.) } & \multirow[b]{2}{*}{ Reference } \\
\hline & $\mathrm{Cu}$ & $\mathrm{Fe}$ & $\mathrm{Cd}$ & \\
\hline FAO & 100 & - & 0.17 & {$[21]$} \\
\hline FAO/WHO limit & 100 & - & 1.67 & {$[22]$} \\
\hline WHO & 100 & 333.3 & 3.33 & [13] \\
\hline European community & - & - & 0.17 & [23] \\
\hline England & 66.67 & - & 0.67 & {$[24]$} \\
\hline
\end{tabular}

Table 2. Heavy metals in muscles ( $\mu \mathrm{g} / \mathrm{g}$ dry. wt.) of fish from the Red Sea and other regions.

\begin{tabular}{|c|c|c|c|c|c|c|}
\hline \multirow{2}{*}{ Fish Species } & \multicolumn{6}{|c|}{ Heavy metals in fish muscles ( $\mu \mathrm{g} / \mathrm{g}$ dry. wt.) } \\
\hline & Site & $\mathrm{Cu}$ & $\mathrm{Zn}$ & $\mathrm{Cr}$ & $\mathrm{Cd}$ & Reference \\
\hline Acanthopagurus bifaclatus & Red Sea & 0.51 & 4.34 & 0.72 & 0.26 & [25] \\
\hline Ctenochaetus striatus & Gulf of Aqaba,Red Sea & 0.87 & 21.38 & 1.36 & 0.83 & [26] \\
\hline Lethrinus sp. & Red Sea & 0.40 & 8.00 & 0.34 & 0.45 & [27] \\
\hline Scomberomrus commerson & Yemen, Gulf Aden & 1.30 & 8.00 & 0.90 & 0.39 & [28] \\
\hline Boops boops & Black Sea & 3.08 & 6.81 & 0.22 & 0.10 & [29] \\
\hline Thunnus thynnus & Mediterranean Sea & 1.01 & 16.54 & 0.74 & 0.05 & [30] \\
\hline Nemipterus japonicas & Hurghada, Red Sea & 0.28 & 2.13 & 0.82 & 0.02 & [31] \\
\hline Caranxsex faciatus & Jeddah coast, Red Sea & 0.91 & 5.33 & 0.00 & 0.90 & [32] \\
\hline
\end{tabular}


which agrees with the previous studies for the other fishes of the Gulf of Aqaba in which Kidney and liver is the sink of these heavy metals, and the detoxification site. The metal concentrations in the examined fish species from the Gulf of Aqaba were below the permissible limits for human consumption reported by WHO [13].

\section{Acknowledgements}

The authors would like to thank the efforts of the staff of the Marine Science Station in Aqaba, mainly Shadia Al-Riyati, for all the help she provided during the digestion, reading of the samples using Atomic Absorption Spectrophotometer. The Authors would like to thank the financial support and logistic cooperation with NATO project SFP. No. 982220.

\section{References}

[1] Duruibe, J.O., Ogwuegbu, M.C. and Egwurugwu, J.N. (2007) Heavy Metal Pollution and Human Biotoxic Effects. International Journal of Physical Sciences, 2, 112-118.

[2] Huang, B.W. (2003) Heavy Metal Concentrations in the Common Benthic Fishes Caught from the Coastal Waters of Eastern Taiwan. Journal of Food and Drug Analysis, 11, 324-330.

[3] Mansour, S.A. and Sidky, M.M. (2002) Ecotoxicological Studies. 3. Heavy Metals Contaminating Water and Fish from Fayoum Governorate, Egypt. Food Chemistry, 78, 15-22. http://dx.doi.org/10.1016/S0308-8146(01)00197-2

[4] Wahbeh, M.I. and Mahasneh, D.M. (1987) Concentrations of Metals in the Tissues of Six Species of Fish from Aqaba, Jordan. Dirasat, 14, 119-129.

[5] Al-Zgool, A. (2008) Levels of Trace Metals in Food Chain of Some Carnivores Fishes (Family: Carangidae) Collected from the Gulf of Aqaba, Red Sea. Master's Thesis, Hashemite University, Zarka.

[6] Batayneh, M. (2010) Levels of Trace Metals in Some Herbivorous Fish of Gulf of Aqaba, Red Sea. Master's Thesis, Hashemite University, Zarka.

[7] Abu-Hilal, A.H. and Ismael, N.S. (2008) Heavy Metals in Eleven Common Species of Fish from the Gulf of Aqaba, Red Sea. Jordan Journal of Biological Sciences, 1, 13-18.

[8] Khalaf, M.A., Al-Najjar, T., Alawi, M. and Disi, A.M. (2012) Levels of Trace Metals in Three Fish Species. Decapterus macrellus, Decapterus macrosoms and Decapterus russelli of the Family Carangidae from the Gulf of Aqaba, Red Sea, Jordan. Natural Science, 4, 362-367. http://dx.doi.org/10.4236/ns.2012.46050

[9] Al-Najjar, T., Abu Khadra, K., Rawashdeh, O.Y., Khalaf, M. and Wahsha, M. (2015) Levels of Trace Metals in (Euthynnus affinis) Fish from the Gulf of Aqaba, Jordan. Fresenius Environment Bulletin, 24, 2995-3000.

[10] Khalaf, M.A and Disi, A.M. (1997) Fishes of the Gulf of Aqaba. Publication of the Marine Science Station, No. 8.

[11] Al-Rousan, S. (2012) Skeletal Extension Rate of the Reef Building Coral Porites Species from Aqaba and Their Environmental Variables. Natural Science, 4, 713-739. http://dx.doi.org/10.4236/ns.2012.49097

[12] Bernhard, M. (1976) Manual of Methods in the Aquatic Environment Research, FAO Fisheries Technical Paper, Food and Agriculture Organisation, No. 158.

[13] Mokhtar, M. (2009) Assessment Level of Heavy Metals in Penaeus monodon and Oreochromis spp. in Selected Aquaculture Ponds of High Densities Development Area. European Journal of Scientific Research, 30, 348-360.

[14] Gorell, J.M., Johnson, C.C., Rybicki, B.A., Peterson, E.L., Kortsha, G.X. and Brown, G.G. (1997) Occupational Exposures to Metals as Risk Factors for Parkinson's Disease. Neurology, 48, 650-658. http://dx.doi.org/10.1212/WNL.48.3.650

[15] Moore, J.W. and Ramamoorthy, S. (1985) Heavy Metals in Natural Waters. Springer-Verlag, New York.

[16] WHO (1992) Environmental Health Criteria. Cadmium-Environmental Aspects, No. 135, World Health Organisation, Geneva.

[17] Mormede, S. and Davies, I.M. (2001) Heavy Metal Concentrations in Commercial Deep-Sea Fish from the Rockall Trough. Continental Shelf Research, 21, 899-916. http://dx.doi.org/10.1016/S0278-4343(00)00118-7

[18] Dalman, Ö., Demirak, A. and Balci, A. (2006) Determination of Heavy Metals (Cd, Pb) and Trace Elements (Cu, Zn) in Sediments and Fish of the Southeastern Aegean Sea (Turkey) by Atomic Absortion Spectrometry. Food Chemistry, 95, 157-162. http://dx.doi.org/10.1016/j.foodchem.2005.02.009

[19] Anan, Y., Kunito, T., Tanabe, S., Mitrofanov, I. and Aubrey, D.G. (2005) Trace Element Accumulation in Fishes Collected from Coastal Waters of the Caspian Sea. Marine Pollution Bulletin, 51, 882-888. http://dx.doi.org/10.1016/j.marpolbul.2005.06.038

[20] Türkmen, M., Türkmen, A., Tepe, Y., Ates, A. and Gökkus, K. (2008). Determination of Metal Contaminations in Sea 
Foods from Marmara, Aegean and Mediterranean Seas: Twelve Fish Species. Food Chemistry, 108, 794-800. http://dx.doi.org/10.1016/j.foodchem.2007.11.025

[21] FAO (1983) Compilation of Legal Limits for Hazardous Substances in Fish and Fishery Products. FAO Fishery Circular No. 464, Food and Agriculture Organization, 5-100.

[22] FAO/WHO (1989) Evaluation of Certain Food Additives and the Contaminants Mercury, Lead and Cadmium. WHO Technical Report Series No. 505.

[23] EC (European Community) (2005) Commission Regulation No. 78. Official Journal of the European Union, L16/43L16/45.

[24] MAFF (Ministry of Agriculture, Fisheries and Food) (1997) Monitoring and Surveillance of Non-Radioactive Contaminants in the Aquatic Environment and Activities Regulating the Disposal of Wastes at Sea. In: Aquatic Environment Monitoring Report No. 52, Center for Environment, Fisheries and Aquaculture Science, Lowestoft.

[25] Abdelmoneim, M., Khaled, A. and Iskander, M. (1994) A Study on the Levels of Some Heavy Metals in EL-Mex, West of Alexandria, Egypt. Proceedings of the 4th Conference of the Environment Protection, 10-12 May 1994, 155174.

[26] Ismail, N.S. and Abu-Hilal, A.H. (2008) Heavy Metals in Three Commonly Available Coral Reef Fish Species from the Jordan Gulf of Aqaba, Red Sea. Jordan Journal of Biological Sciences, 2, 61-66.

[27] Abdelmoneim, M.A. and El-Deek, M.S. (1992) Lethrinus Family: A Model of Edible Red Sea Fish with Low Heavy Metals Accumulation. National Institute of Oceanography and Fisheries, 19, 589-596.

[28] Al-Adrise, M.A.M. (2002) Concentration of Some Heavy Metals in Khor-Kutheb Area (Al-Hodiedah) as a Result of the Sewage Effluent Impacts. M.Sc Thesis, Faculty of Science, Sana'a University, Sana’a.

[29] Gorur, F.K., Keser, R., Akcay, N. and Dizman, S. (2012) Radioactivity and Heavy Metal Concentrations of Some Commercial Fish Species Consumed in the Black Sea Region of Turkey. Chemosphere, 87, 356-361. http://dx.doi.org/10.1016/j.chemosphere.2011.12.022

[30] Hussein, A. and Khalid, A. (2014) Determination of Metals in Tuna Species and Bivalves from Alexandria, Egypt. Egyptian Journal of Aquatic Research, 40, 9-17. http://dx.doi.org/10.1016/j.ejar.2014.02.003

[31] El-Moselhy, K.H.M., Othman, A.I., Abd El-Azem, B.H. and El-Metwally, M.E.A. (2014) Bioaccumulation of Heavy Metals in Some Tissues of Fish in the Red Sea, Egypt. Egyptian Journal of Basic and Applied Sciences, 1, 97-105. http://dx.doi.org/10.1016/j.ejbas.2014.06.001

[32] Ali, A.A., Elazein, E.M. and Alian, M.A. (2011) Investigation of Heavy Metals Pollution in Water, Sediment and Fish at Red Sea-Jeddah Coast-KSA at Two Different Locations. Journal of Applied Environmental Biological Sciences, 1, 630-637.

\section{Scientific Research Publishing}

\section{Submit or recommend next manuscript to SCIRP and we will provide best service for you:}

Accepting pre-submission inquiries through Email, Facebook, Linkedin, Twitter, etc

A wide selection of journals (inclusive of 9 subjects, more than 200 journals)

Providing a 24-hour high-quality service

User-friendly online submission system

Fair and swift peer-review system

Efficient typesetting and proofreading procedure

Display of the result of downloads and visits, as well as the number of cited articles

Maximum dissemination of your research work

Submit your manuscript at: http://papersubmission.scirp.org/ 